\title{
Freedom of Religion and Minority Rights in South Africa
}

\author{
Yonatan T. Fessha ${ }^{1, *}$ and Beza Dessalegn 1,2 \\ 1 Department of Public Law and Jurisprudence, University of the Western Cape, Cape Town 7535, South Africa; \\ bezadesy4722@gmail.com \\ 2 School of Law, College of Law and Governance, Hawassa University, Hawassa P.O. Box 05, Ethiopia \\ * Correspondence: yfessha@gmail.com
}

\begin{abstract}
The South African Constitution contains an extensive list of rights, several of which are relevant, directly or indirectly, to accommodate the needs of persons that belong to a religious minority group in South Africa. This article examines the extent to which these protections are utilized by individuals and courts and explores the interplay between these various sources of protection that religious minority groups and their members can rely on. It will examine the courts case law on freedom of religion to determine whether the courts have relied on one or all of the rights offered by the Constitution when dealing with claims made by persons belonging to a religious minority group. The reasons for and impacts of the choices that the courts have made will also be investigated. Equally important are the choices made by persons belonging to a religious minority group when approaching courts to vindicate their rights.
\end{abstract}

Keywords: religious freedom; religious minorities; Bill of Rights; Constitutional Court; South Africa

check for

updates

Citation: Fessha, Yonatan T., and Beza Dessalegn. 2021. Freedom of Religion and Minority Rights in South Africa. Religions 12: 901. https://doi.org/10.3390/rel12100901

Academic Editors: Silvio Ferrari, Roberta Medda-Windischer and Kerstin Wonisch

Received: 4 August 2021

Accepted: 19 September 2021

Published: 19 October 2021

Publisher's Note: MDPI stays neutral with regard to jurisdictional claims in published maps and institutional affiliations.

Copyright: (c) 2021 by the authors. Licensee MDPI, Basel, Switzerland. This article is an open access article distributed under the terms and conditions of the Creative Commons Attribution (CC BY) license (https:/ / creativecommons.org/licenses/by/ $4.0 /)$.

\section{Introduction}

Religion constitutes an important part of the identity of many South Africans. Yet, South Africa's legacy of colonial rule and group-based discrimination means that "religious apartheid" has characterized its past and continues to impact its present. ${ }^{1}$ This suggests that a constitutional response to the accommodation of religious diversity was unavoidable. Owing to the significant emphasis placed on promoting national unity and nation building, however, the protection of religious diversity was not among the issues that dominated the 1996 constitution-making process (Henrard 2001, p. 53; Leatt 2017, pp. 61-66). Yet, the current constitution of South Africa does not go without recognizing and accommodating religious diversity.

The South African Constitution contains an extensive list of rights, including traditional civil and political rights, as well as socio-economic rights. Several rights are relevant, directly or indirectly, to protect the interests of persons that belong to a religious minority group in South Africa. The protection of religious diversity has also benefited from important decisions made by the courts. In particular, the Constitutional Court has given effect to the commitments of the Constitution to religious pluralism by expounding the concept of religious freedom, emphasizing the constitutional recognition of religious diversity and extending the protection available for persons belonging to religious minorities.

This article examines the extent to which the constitutional protections available to religious minorities are utilized by individuals and courts. It examines the interplay between the various rights that religious minority groups and their members can rely on. It examines the courts' case law on freedom of religion to determine whether the courts have relied on one or all of the rights offered by the Constitution when dealing with claims made by persons belonging to a religious minority group. Equally important are the choices made by persons belonging to a religious minority group when approaching courts to vindicate their rights.

This article is structured as follows. The next section provides a brief overview of religious diversity and the historical place of religious minorities in South Africa. This is 
followed by a discussion that describes the constitutional framework for the protection of persons belonging to religious minorities. This article then focuses on the jurisprudence of the Constitutional Court and investigates the extent to which persons belonging to religious minorities have been given protection. This article concludes with brief remarks.

\section{Religious Diversity and Religious Minorities in South Africa: A Historical Perspective}

South Africa had no state religion. There is no doubt, however, that the state sought to privilege Christianity. At the same time, Christianity provided a theological justification of apartheid. Several Christian churches actively promoted racial divisions, with the Dutch Reformed Church, which was also the 'official religion' of the National Party, the ruling party during apartheid, playing a prominent role (Du Plessis 2016, p. 240). Although racial discrimination was the principal form of exclusion implemented by the apartheid government, religion was also used to further divide and rule the population.

Although South Africa does not collect data on religious affiliation in its census since 2001, it is well established that the great majority of South Africans-close to eighty percent of them-profess different variants of Christianity. ${ }^{2}$ In fact, according to a General Household Survey published in 2015, the number of South African population that adheres to the different variants of the Christian faith stands at 86 percent (General Household Survey 2015). The rest belong to different religious minority groups, including Hinduism, Islam, Judaism, and traditional African beliefs. While adherents of the Christian faith constitute more than eighty percent, no one particular form of Christianity constitutes a majority. That is what Coertzen had in mind when he concluded that "there are no majorities in South Africa-all are minorities" (Coertzen 2014, p. 127).

South Africa, numerically speaking, might be a country of religious minorities. In terms of the actual power that religious groups held, however, some were more equal than others. Because the state associated itself with a particular form of Christianity, other religions were relegated to a secondary status. The history of religious marginalization that was directed to Muslims and adherents of traditional African religions tells the story of vulnerable religious groups (Coertzen 2014, pp. 127-28; Dangor 1992, pp. 376-80). For instance, a law forbade Muslims that were brought to the Cape in the 17th century from practicing their religion publicly. During the days of apartheid, Muslims often had difficulty accessing opportunities in the areas of education and the economy. Muslim personal and family laws were not recognized. The same was true with the traditional African religions or beliefs. For instance, the Witchcraft Suppression Act criminalizes claiming knowledge of witchcraft and conducting specified practices associated with witchcraft, including the use of charms and divination (Sapra 2007; Van Coller 2020, pp. 88-90). Given that African traditional religions often are associated with spirits and the spirit world, legislation like the Witchcraft Suppression Act, which is still in operation, have the disproportional effect of criminalizing the pursuance of indigenous African religions. Thus, Muslim, Hindu and African systems of family law that recognize polygamous marriages were without any legal recognition (Amien 2006, p. 733). While African customary marriages have now been given recognition by the Customary Marriages Act of 1998, which came into force on 15 November 2000, a similar recognition is not extended to marriages concluded in terms of a system of law under Muslim, Hindu or other minority religions.

From the foregoing, it is clear that the apartheid government did not recognize the religious diversity that characterized the South African society. While Christianity has never been proclaimed a state religion during apartheid, it was nevertheless the dominant religion that, arguably, enjoyed the unofficial official status as a state religion. The government favored Christianity at the expense of others. The consequence of this was the marginalization of persons belonging to religious minority groups. The South African experience confirms the general observation that a country is bound to have religious minorities if the policies and actions of the state favor a particular religion. Post apartheid South Africa was surely expected to address this unequal recognition and treatment of religions. 
The question is therefore whether and to what extent the post-apartheid constitutional dispensation accommodates religious diversity and in particular, religious minorities. That is the focus of the next section.

\section{Protection of Freedom of Religion: The Constitutional Framework}

The South African Constitution recognizes several rights that are relevant, directly or indirectly, to accommodate the needs of persons that belong to a religious minority group. On the one hand, persons belonging to religious minorities benefit from the protections extended to every individual who seeks his or her right to freedom of religion is respected. One such protection relates to the right to equality and non-discrimination. Section 9 of the Constitution states that 'everyone is equal before the law and has the right to equal protection and benefit of the law'. Furthermore, the state is prohibited from unfairly discriminating directly or indirectly against anyone on one or more grounds, including religion. Section 9(4) of the Constitution extends the application of the equality guarantee horizontally by stating that no person may unfairly discriminate directly or indirectly against anyone. The constitutional prohibition of non-discrimination is strengthened with the adoption of Promotion of Equality and Prevention of Unfair Discrimination Act 2000 that gives effect to section 9(4) of the Constitution. The horizontal applicability of the equality provision is central to the protection of religious minorities as the threat to freedom of religion comes not only from governmental authorities but also from private persons. The right to equality and non-discrimination is relevant for the protection of religious minorities as equal treatment of their members and protection from discrimination is one of the common demands of religious minority groups.

Another protection that the constitution makes available to everyone, majorities and minorities alike, is provided in section 15(1) of the Constitution, which protect the right of everyone to freedom of religion, belief and conscience. The individual orientation of the right to freedom of religion protected under section 15 of the Constitution is evident. As Justice $\mathrm{O}^{\prime}$ Regan explained "[b]y associating religion with belief and conscience, which involve an individual's state of mind, religion is understood in an individualist sense: a set of beliefs that an individual may hold regardless of the beliefs of others" (MEC for Education: Kwazulu-Natal v Navaneethum Pillay 2007, para. 143). The free exercise of religion is extended to educational institutions (Fourie 2003, p. 101). Section 15(2) of the Constitution provides that "Religious observances may be conducted at state or state-aided institutions, provided that-(a) those observances follow rules made by the appropriate public authorities; (b) they are conducted on an equitable basis; and (c) attendance at them is free and voluntary". Section 15(3) of the Constitution allows the recognition of religious systems, particularly in matters of family law. It provides for the possibility of enactment of a legislation that recognize '(i) marriages concluded under any tradition, or a system of religious, personal or family law; or (ii) systems of personal and family law under any tradition, or adhered to by persons professing a particular religion'. Although this provides for the possibility of recognition of non-Christian faith marriages and other personal and family matters to be regulated by religious laws, thereby, accommodating religious minorities, it is also criticized for failing to put a positive obligation on the state 'to recognize religious practices and religious laws'. This is evident from the negative formulation of section 15(3) of the Constitution. The legislature is not obliged to 'recognize religious practices and religious law' but to do so if it wishes. This means that the legislature can choose 'not to pass any law at all that will recognize religious practices or law'.

In practice, the South African government enacted the Recognition of Customary Marriages Act in 1998 pursuant to the spirit of section 15 of the Constitution. However, the recognition of Muslim marriages and the application of a Muslim personal law have both been sensitive and divisive (Dangor 1992, pp. 379-80). Despite the more than two decades of effort, it has not still been possible to come up with a Muslim personal law, which recognizes the validity of Muslim marriages (Amien and Leatt 2014, p. 505). In August 2019, the High Court in Western Cape ruled that the state has failed to fulfil its 
constitutional obligation to recognize Muslim marriages and to regulate the consequences of such recognition. It gave the state a period of two years to enact a legislation that recognizes Muslim marriage as valid marriage for all purposes in South Africa. The matter is now brought before the Supreme Court of Appeal. Part of the concern underlying the appeal is the view that the ruling of the High Court has failed to address the plight of Muslim women who need immediate legal recognition of their marriages and cannot wait for another two years. As we are busy finalizing this article, the matter is heard by the SCA and judgment is reserved. ${ }^{3}$

In addition to the protections of freedom of religion that are available to everyone and from which persons belonging to religious minorities can benefit, there are also specific clauses that aim at protecting individuals who belong to a minority group. Section 31 of the Constitution, in almost the same exact words as Article 27 of the International Covenant on Civil and Political Rights, states that persons belonging to a religious community may not be denied the right, with other members of that community, to practice their religion, to join and maintain religious associations. ${ }^{4}$ As a constitutional clause that "protect[s] the rights of individuals within communities to pursue cultural practices", this is an important right that protects diversity within South Africa (MEC for Education: Kwazulu-Natal v Navaneethum Pillay 2007, para. 150). Henrard argued that this provision can be regarded as a minority rights provision (Henrard 2001, p. 67). Some take it further and argue that the provision envisions group rights, making it possible to force the state to take positive measures (Heyns and Brand 2000, p. 90; Henrard 2001, p. 60). Those that espouse this particular understanding of the rights provided under section 31(1) point to the individual and collective dimension of religious freedom emphasized by the Constitutional Court in Christian Education South Africa v Minister of Education:

Just as it is difficult to postulate a firm divide between religious thought and action based on religious belief, so it is not easy to separate the individual religious conscience from the collective setting in which it is frequently expressed. Religious practice often involves interaction with fellow believers. It usually has both an individual and a collective dimension and is often articulated through activities that are traditional and structured, and frequently ritualistic and ceremonial. (Christian Education South Africa v Minister of Education 2000, para. 19)

It is not clear, however, if acknowledging the individual and collective dimension of religious practice implies that the right under section 31(1) of the Constitution is extended to groups. That is why others contend that the rights in section 31(1) of the Constitution, are individual rights (Henrard 2001, p. 58), which puts negative obligation on the part of the state not to interfere with the right. In Pillay, Justice O'Regan argued that "sections 30 and 31 are associative rights exercised by individual human beings and are not rights that attach to groups" (MEC for Education: Kwazulu-Natal v Navaneethum Pillay 2007, para. 150). Furthermore, considering that individuals who belong both to majority and minority groups can clam protection under section 31, the latter, unlike Henrard's claim, can hardly be considered as a minority right. At best, it is a diversity right. The absence of a protection that is dedicated to individuals who belong to minority groups might suggest a constitution that does not appreciate the vulnerable status of minority communities. However, it is also a reflection of a constitution that is seeking to move away from an era when minority rights were used to oppress the majority and emphasizes national unity (Fessha 2010).

From the foregoing, it is also clear that a person who belongs to a religious minority group has the benefit of claiming protection both from the protections of freedom of religion that are available to everyone but also from the diversity right that section 31 of the Constitution provides. As the Court indicated, there may be an overlap between the protections offered under the prohibition of non-discrimination based on religion and the rights of individuals to freedom of religion (section 15) and to practice religion (section 31). In Pillay, the claim was brought primarily based on the right to non-discrimination based on religion. However, in order to establish discrimination, Ms. Pillay needed to show that 
the decisions of the school "in some way interfered with [the right to] participation in or practice or expression of ... religion or culture" (MEC for Education: Kwazulu-Natal v Navaneethum Pillay 2007, para. 46). This is consistent with the view that "[a]propriate responses to abuses inflicted on religious minorities and their members require a holistic understanding of the various human rights norms involved in such situations, in compliance with the principle that '[a]all human rights are universal, indivisible and interrelated and interdependent'" (Bielefeldt et al. 2016, p. 451).

In as much as there is a possibility of overlap, it must also be noted that the protection of religion based on the prohibition of discrimination is distinct from the protection of religion and culture provided for by sections 15 and 31 of the Constitution (MEC for Education: Kwazulu-Natal v Navaneethum Pillay 2007, para. 46). A person may be discriminated on the basis of religion even though his or her freedom of religion is not interfered with. This, as the Court mentioned, would be the case, for example, "where one religion is treated in an inferior manner". Furthermore, it does not seem that a person who relies on the protection available under sections 15 and 31 has a more onerous burden to prove than a person who relies on the prohibition of discrimination on the basis of religion. In fact, the opposite might be true under certain circumstances. This is the case, for example, where the discrimination in question flows from an interference with a person's "religious or cultural practices". In this case, an applicant that relies on the equality clause has the additional task of proving that the discrimination is unfair as not all discrimination, according to the South African Constitution and the relevant legislation, are constitutionally problematic. The applicants in the Pillay case had to prove that the decision of the school to ban Pillay not only "interfered with Sunali's participation in or practice or expression of her religion or culture" but also constituted unfair discrimination on the basis of religion as outlined in the Promotion of Equality and Prevention of Unfair Discrimination Act. ${ }^{5}$

As is the case with most rights, the right to freedom of religion has limitations. Realizing religious freedom requires a careful and considerate constitutional balance. It can only be practiced to the extent that its enjoyment does not jeopardize the exercise of the fundamental rights of others (Henrard 2001, p. 61). ${ }^{6}$ As stated under section 31(2) of the Constitution, the right of individuals to participate in activities of religious communities may not be exercised in a manner that offends the Bill of Rights. According to the Constitutional Court, this stipulation serves a dual purpose. Its first purpose "is to prevent protected associational rights of members of communities from being used to "privatize" constitutionally offensive group practices and thereby immunize them from external legislative regulation or judicial control" (Christian Education South Africa v Minister of Education 2000, para. 26). Its other purpose is protecting members of a religious community from being subjected to oppressive practices in the name of religious freedom. Accordingly, the Constitutional Court, in Christian Education South Africa v Minister of Education, ruled that a parental administration of corporal punishment, which was delegated to teachers in order for them to administer corporal punishment against learners in schools, is inconsistent with the Bill of Rights (Ibid, para. 51). Similarly, in Freedom of Religion South Africa v Minister of Justice and Constitutional Development and Others, the Constitutional Court ruled that the common law defense of moderate and reasonable chastisement against a child whose parents view such an action as a Christian value permissible by holy scriptures and writings is inconsistent with the provisions of sections 10 and 12(1)(c) of the Constitution (Freedom of Religion South Africa v Minister of Justice and Constitutional Development and Others 2019, paras. 9, 34, 76). In both cases, the court demonstrated that any action that goes against the Bill of Rights provisions could not be defended based on freedom of religion or religious belief (Coertzen 2008, p. 436).

Moreover, in a South African context, religious freedoms are subject to the general limitation clause of section 36 where competing interests are required to be balanced. The limitation can only be made based on a law of general application, which could be a legislation or common law. Limitations imposed should be 'reasonable and justifiable' in 
an open and democratic society based on human dignity, freedom and equality taking into account certain factors, such the nature of the right, the importance of the purpose of the limitation, the nature and extent of the limitation, the relation between the limitation and its purpose and the availability of less restrictive means to achieve the purpose.

\section{Protection of Religious Minorities in the Courts: The Perspective from the Constitutional Court}

Undoubtedly, the 1996 constitutional dispensation has opened a new platform to address the quest for religious freedom, providing a wide array of rights that individuals can rely on to affirm and protect their freedom of religion. The next task is to examine the courts' case law on freedom of religion in order to determine whether the courts have relied on one or all of the rights offered by the Constitution when dealing with claims made by persons belonging to a religious minority group. ${ }^{7}$ Equally important are the choices made by persons belonging to a religious minority group when approaching courts to vindicate their rights. The focus is largely on the jurisprudence of the Constitutional Court, the highest court of the land.

It is interesting to note that individuals who belong to a religious minority group rely both on the protection available to everyone and those available to persons belonging to minority groups. This was, for example, the case in Prince v President of the Law Society of the Cape of Good Hope (Prince). In that case, Mr. Prince, an adherent of the Rastafari religion and a law graduate, sought to qualify as attorney. An important requirement to be admitted as an attorney is the completion of a community of service. Although $\mathrm{Mr}$ Prince entered into a community of service, the Secretary of the Law Society of the Cape of Good Hope (the law society) refused to register his contract (Prince v President of the Law Society of the Cape of Good Hope 2002, para. 2). The Law Society based its decision on the Attorneys Act 53 of 1979, which required proof to the satisfaction of the society that the person wishing to register is a fit and proper person. Mr. Prince had two previous convictions for the possession of cannabis and that he had also made it clear that he, as a follower of the Rastafari religion, intends to continue to use cannabis. Based on that, the law society refused to register the applicant. Mr. Prince challenged the Drugs and Drug Trafficking Act 104 of 1994 and the Medicines and Related Substances Control Act 101 of 1965 on the ground that the Acts fail to provide an exemption to persons requiring the possession and use of marijuana for religious purposes (Ibid, para. 6). He argued that the absence of an exemption violates his freedom of religion. He based his claim on section 15 of the Constitution that extends freedom of religion to every individual. However, he also made the claim based on section 31 of the Constitution, which protects the right of an individual who belongs to a religious minority group to practice his or her religion (Ibid, para. 6, 27).

Member of the Executive Council for Education: Kwazulu-Natal and Others v Pillay (Pillay) is another relevant case involving a female student who wanted to wear a nose stud in school, which she received from her mother as part of a Hindu coming-of-age tradition. Ms. Pillay was informed by the school that her daughter was not allowed to wear the nose stud as it was in violation of the Code of Conduct of the school. After a period of correspondence between the school and Sunali Pillay's mother, the school decided that the learner should not be allowed to wear the stud in the school. When she refused, the school started disciplinary proceedings. The learner's mother took the school to the courts and the matter eventually went to the Constitutional Court. Although the case of Ms. Pillay, a member of a religious minority group in South Africa, was primarily made based on the prohibition of unfair non-discrimination, she also sought to rely on freedom of religion as an independent claim (MEC for Education: Kwazulu-Natal v Navaneethum Pillay 2007, para. 28).

What about the court? Has it relied on one or all of the rights offered by the Constitution when dealing with claims made by persons belonging to a religious minority group? To begin with, it is important to note that the Constitutional Court has, time and again, 
emphasized the commitment of the constitution to the protection of religious diversity and hence the protection of minority religions:

The right to freedom of religion is especially important for our constitutional democracy which is based on human dignity, equality and freedom. Our society is diverse. It is comprised of men and women of different cultural, social, religious and linguistic backgrounds. Our Constitution recognizes this diversity. This is apparent in the recognition of the different languages; the prohibition of discrimination on the grounds of, amongst other things, religion, ethnic and social origin; and the recognition of freedom of religion and worship. The protection of diversity is the hallmark of a free and open society. (Prince v President of the Law Society of the Cape of Good Hope 2002, para. 49)

It seems that the courts are acutely aware of the vulnerable position of religious minorities compared to members of the majority community that can rely on the legislative process to effect their wishes. The special value of the Bill of Rights to members of a minority community is duly emphasized. In the words of the Constitutional Court, 'it might well be that in the envisaged pluralistic society members of large groups can more easily rely on the legislative process than can those belonging to smaller ones, so that the latter might be specially reliant on constitutional protection, particularly if they express their beliefs in a way that the majority regard as unusual, bizarre or even threatening ${ }^{\prime}{ }^{8}$ At the same time, the Court has warned against the abuse of religious pluralism to license the privatization of "offensive group practices" and internal domination. It is important to note here, while the protection of religious freedoms is important to allow members of a particular faith to exercise their religious beliefs, it is at the same time necessary to ensure that adherents of a certain belief are not subject to inward restrictions or abuses that go against their fundamental rights and freedoms.

When dealing with claims of religious protection, the Constitutional Court, albeit implicitly, seems to have adopted a three-prong balancing test (Ibid; MEC for Education: Kwazulu-Natal v Navaneethum Pillay 2007). The test involved ascertaining (1) whether the applicant's religion, from which the constitutional claim emerged, is a recognized religion; (2) whether the practice to which the applicant is seeking protection is an important aspect of the religion; and (3) whether the applicant's belief in the religious practice is genuine. As the following discussion reveals, the manner in which the Court addressed these questions gives ample room for the protection of religious minorities.

In addressing the first question, the Court in Prince quickly concluded that "Rastafari is a religion that is protected by sections 15 and 31 of the Constitution" (Prince v President of the Law Society of the Cape of Good Hope 2002, paras. 15, 97). The court automatically recognized Rastafari as an established religion. Similarly, in Pillay, the court did not dispute whether or not Hinduism is a religion (MEC for Education: Kwazulu-Natal v Navaneethum Pillay 2007, para. 48). The readiness of the court to acknowledge minority religions is important. First, it signifies that the Constitution protects both big and small, traditional and recent religions. Second, persons belonging to religious minorities do not have to carry the additional burden of proving the existence of their religions.

An important boost to the protection of minority religions is also how the Court opted to deal with the second question, namely whether the practice under consideration forms a central tenet of the religion. In Prince, the court has made it clear that it is not the business of the Court to be concerned with whether a particular practice is central to a religion:

Religion is a matter of faith and belief. The beliefs that believers hold sacred and thus central to their religious faith may strike non-believers as bizarre, illogical or irrational. Human beings may freely believe in what they cannot prove. Yet, that their beliefs are bizarre, illogical or irrational to others or are incapable of scientific proof, does not detract from the fact that these are religious beliefs for the purposes of enjoying the protection guaranteed by the right to freedom of religion. The believers should not be put to the proof of their beliefs or faith. 
For this reason, it is undesirable for courts to enter into the debate whether a particular practice is central to a religion unless there is a genuine dispute as to the centrality of the practice. (Prince $v$ President of the Law Society of the Cape of Good Hope 2002, para. 42)

In Prince, since the use of cannabis is claimed to be central to religion by Mr. Prince and that these allegations are not denied, the Court concluded that they must therefore be accepted (Ibid, para. 43). In Pillay, the court likewise ruled that the practice of a certain religious activity should be subjectively assessed. It held that "[i]f Sunali states that the nose stud is central to her as a South Indian Tamil Hindu, it is not for the Court to tell her that she is wrong because others do not relate to that religion or culture in the same way" (MEC for Education: Kwazulu-Natal v Navaneethum Pillay 2007, para. 87). ${ }^{9}$ The court's reliance on a subjective assessment of what particular action or inaction constitutes a central aspect of religion allows for a wider protection of practices of religious minorities.

Linked to this is the decision of the Court to protect both voluntary and obligatory practices. According to the Court, whether a person performs a particular practice voluntarily or out of obligation does not affect the determination of whether the practice deserves a constitutional protection. This is consistent with the commitment of the constitution not only to protect diversity but also celebrate diversity. "Differentiating between mandatory and voluntary practices does not celebrate or affirm diversity, it simply permits it" (Ibid, para. 65). Doing so, the Court argued, "falls short of our constitutional project which not only affirms diversity, but promotes and celebrates it. We cannot celebrate diversity by permitting it only when no other option remains" (Ibid).

The other question the courts had to determine was the genuineness of the claimant's religious belief. This is partly about active membership and belonging. In general, membership to a minority group is a complex matter as it involves the consideration of both objective and subjective elements (Capotorti 1979). Different countries use different approaches for the determination of the perception of belonging and membership. The South African approach seems to be in line with the general trend of making self-identification occupy a central place in determining membership to religious minorities. In Prince, the court stated that "there is no question about the genuineness of the appellant's religious belief" as "[h]e has demonstrated that he is a bona fide member of the Rastafari religion" (Prince v President of the Law Society of the Cape of Good Hope 2002, para. 43). In Pillay, the decision of the student to consistently wear the nose stud in spite of the ill treatment by her peers and media exposure convinced the court to conclude "that Sunali held a sincere belief that the nose stud was part of her religion and culture" (MEC for Education: Kwazulu-Natal v Navaneethum Pillay 2007, para. 58). In both cases, the court relied on the statements and actions made by the claimants that they are sincere members of the religion to which they claim to be associated and that no dispute was raised by the other parties. It therefore based its assessment on the subjective decisions of the parties to claim membership. ${ }^{10}$

One the other hand, it must be mentioned that the court in the Pillay case accepted an amicus curiae from a religious organization (MEC for Education: Kwazulu-Natal v Navaneethum Pillay 2007, para. 22, 23). In Prince, the applicant was allowed to introduce evidence from a religious expert who has written extensively on cultural and religious practices of the Rastafari (Prince v President of the Law Society of the Cape of Good Hope 2002, para. 12). Since both expert opinions endorsed the claims of the applicant, there was no apparent conflict. It would be interesting to see which one would have taken precedence if the expert opinions differed with that of the claimants and why. Similarly, it could be argued, in both cases, because Rastafarianism and Hinduism are well-known religions across the world, the court simply relied on the self-identification of the claimants. It would be interesting to note whether a similar approach would be taken if the court was presented with a lesser known religion or religious groups (Mhango 2012, p. 29). 


\section{Conclusions}

The South African Constitution contains an extensive list of rights. The discussion has revealed that several rights are relevant, directly or indirectly, to accommodate the needs of persons that belong to a religious minority group in South Africa. The state is enjoined not to unfairly discriminate directly or indirectly against anyone on one or more grounds including religion. Article 15 of the Constitution protects freedom of religion. Moreover, the Constitution, in almost the same exact words as Article 27 of the International Covenant on Civil and Political rights, affirms the right of persons belonging to a religious community to practice their religion. It is clear that religious minority groups in South Africa can benefit from a wide array of rights that aim at protecting individuals and minority communities. Given South Africa's past of Christian dominance, the level of constitutional recognition and protection extended to minority religions is encouraging. The commitment of the courts to religious diversity is palpable. Although the courts have not specifically relied upon the diversity right that the Constitution makes available, they have effectively used the right to freedom of religion available to everyone to protect the right of persons belonging to religious minorities to manifest their religion. It is submitted that the commitment of the constitution to religious diversity, as confirmed by the Constitutional Court, nudges both governmental and private actors toward reasonable accommodation of religious minorities.

Author Contributions: All sections have been written, reviewed and edited by all authors. All authors have read and agreed to the published version of the manuscript.

Funding: This research received no external funding.

Conflicts of Interest: The authors declare no conflict of interests.

\section{Notes}

1 While apartheid in South Africa generally connotes a system of institutionalized segregation that is based on racial attributes, this racial segregation often had religious dimensions. Because Christianity had a dominant status from the early days of white settlement until the end of apartheid, other religions in South Africa did not enjoy equal status with Christianity (Prozesky 1995, pp. 13-16; Henrard 2001, p. 52; Mhango 2012, pp. 23-50).

2 It should, however, be noted that there are several internal differences within the Christian-adherent population. (Prozesky 1995, p. 11).

3 As Henrard (2001, p. 63) put it "the paradox is on "how to find an appropriate balance between the right to religious identity (section 31) and religious freedom (section 15) on the one hand and the central principle of equality in the new constitutional order on the other hand."

4 At the same time, the Constitution, under section 31(2), states that the right of persons belonging to religious communities may not be exercised in a manner inconsistent with any provision of the Bill of Rights. This is a confirmation that religious rights can only be exercised so long as they do not affect the equality guarantee.

5 This inquiry is similar to an inquiry under sections 15 or 30, but it is not identical because the Court must go on to consider whether the discrimination, if any, was unfair'.

6 Henrard, however, also notes that this approach may also lead to a conclusion that the inconsistency clause, by subjecting identity rights to the Bill of Rights, has attributed lower status to them.

7 While courts occupy the central position in circumstances of infringement of the aforementioned rights (section 38(1)), there are also other independent institutions that are constitutionally founded to look after the Bill of Rights. One such institution is the Commission for the Promotion and Protection of the Rights of Cultural, Religious and Linguistic Communities (section 158, Constitution). The Commission is arranged to be as representative as possible to the communities in South Africa, which also includes religious communities, and its objective being to monitor, investigate, research, educate, advise and report on issues concerning the rights of these communities (section 185(2)).

8 Nevertheless, the interest protected by section 31 is not a statistical one dependent on a counter-balancing of numbers, but a qualitative one based on respect for diversity (Christian Education South Africa v Minister of Education, para. 2).

9 However, unlike in Prince, the court widened the constitutional protection to a sincere practice or belief, by arguing that recognition should be granted regardless of whether the practice or belief is mandatory or voluntary (MEC for Education: Kwazulu-Natal v Navaneethum Pillay 2007, para. 66). The court argued the following: A necessary element of freedom and of dignity of any individual is an "entitlement to respect for the unique set of ends that the individual pursues." One of those ends is the voluntary religious and cultural practices in which we participate. That we choose voluntarily rather than through a feeling of obligation only enhances the significance of a practice to our autonomy, our identity and our dignity (Ibid, para. 64). 
However, as held by the Court in Pillay, "[t]he possibility for abuse should not affect the rights of those who hold sincere beliefs" showing the decision tilting in favor subjective assessment (MEC for Education: Kwazulu-Natal v Navaneethum Pillay 2007, para. 107). Yet, since the basic reason behind checking sincerity is to flush out those who have no genuine connection with the religion from getting unfair advantages while at the same time protecting the rights of those who truthfully adhere to their religion, it would have been interesting to see how the court will proceed in ascertaining sincerity in circumstance of dispute between parties.

\section{References}

Amien, Waheeda. 2006. Overcoming the Conflict between the Right to Freedom of Religion and Women's Rights to Equality: A South African Case Study of Muslim Marriage. Human Rights Quarterly 28: 729-54. [CrossRef]

Amien, Waheeda, and Dhammamegha Annie Leatt. 2014. Legislating Religious Freedom: An Example of Muslim Marriages in South Africa. Maryland Journal of International Law 29: 505-47.

Bielefeldt, Heiner, Nazila Ghanea, and Michael Wiener. 2016. Freedom of Religion or Belief. Oxford: Oxford University Press.

Capotorti, Francesco. 1979. Study on the Rights of Persons Belonging to Ethnic, Religious, and Linguistic Minorities. E/CN.4/Sub.2/384/Rev.1, Sales No E78XIV1. New York: United Nations.

Christian Education South Africa v Minister of Education. 2000. Constitutional Court of South Africa Case CCT 4/00. (4) SA 757. Available online: http:/ / www.saflii.org/za/cases/ZACC/2000/11.html (accessed on 15 October 2021).

Coertzen, Pieter. 2008. Grappling with Religious Differences in South Africa: A Draft for a Charter of Religious Rights. Brigham Young University Law Review 2008: 779-806.

Coertzen, Pieter. 2014. Constitution, Charter and religions in South Africa. African Human Rights Law Journal 14: 126-41.

Dangor, Suleman. 1992. The Muslims of South Africa: Problems and concerns of a minority community. Journal Institute of Muslim Minority Affairs 13: 375-81. [CrossRef]

Du Plessis, Georgia Alida. 2016. Apartheid, Religious Pluralism, and the Evolution of the Right to Religious Freedom in South Africa. Journal of Religious History 40: 237-60. [CrossRef]

Fessha, Yonatan Tesfaye. 2010. Ethnic Diversity and Federalism: Constitution Making in South Africa and Ethiopia. Farnham: Ashgate Publishing Limited.

Fourie, Pieter. 2003. The SA Constitution and Religious Freedom: Perverter or Preserver of Religion's Contribution to The Public Debate on Morality? Scriptura 82: 94-107. [CrossRef]

Freedom of Religion South Africa v Minister of Justice and Constitutional Development and Others. 2019. Constitutional Court of South Africa CCT320/17. SA 34 (CC). Available online: http:/ /www.saflii.org/za/cases/ZACC/2019/34.html (accessed on 15 October 2021).

General Household Survey. 2015, Statistics South Africa. Available online: https:/ / www.statssa.gov.za/publications/P0318/P0318201 5.pdf (accessed on 15 June 2020).

Henrard, Kristin. 2001. The Accommodation of Religious Diversity in South Africa against the Background of the Centrality of the Equality Principle in the New Constitutional Dispensation. Journal of African Law 45: 51-72. [CrossRef]

Heyns, Christof, and Danie Brand. 2000. The constitutional protection of religious human rights in Southern Africa. The Comparative and International Law Journal of Southern Africa 33: 53-95.

Leatt, Dhammamegha Annie. 2017. The State of Secularism: Religion, Tradition and Democracy in South Africa. Johannesburg: Wits University Press.

MEC for Education: Kwazulu-Natal v Navaneethum Pillay. 2007. Constitutional Court of South Africa CCT 51/06. (1) SA 474 (CC). Available online: http:/ / www.saflii.org/za/cases/ZACC/2007/21.html (accessed on 15 October 2021).

Mhango, Mtendeweka. 2012. Recognizing Religion: Emerging Jurisprudence in South Africa. Journal for the Study of Religion 25: 23-50.

Prince v President of the Law Society of the Cape of Good Hope. 2002. Constitutional Court of South Africa CCT36/00. (2) SA 794 (CC). Available online: http:/ / www.saflii.org/za/cases/ZACC/2002/1.html (accessed on 15 October 2021).

Prozesky, Martin. 1995. Religious justice at last? Believers and the new Constitution in South Africa. Journal of Theology of Southern Africa 92: 11-21.

Sapra. 2007. Appeal for Legislative Reform. Available online: https://archive.vn/20121220043355/http://www.vuya.net/node/2677 (accessed on 15 May 2020).

Van Coller, Helena. 2020. Regulating Religion: State Governance of Religious Institutions in South Africa. London: Routledge. 